\title{
Salvador Giner (coord.): Teoría sociológica moderna, Ed. Ariel, Barcelona, 2011, 678pp.
}

El sociòleg Wright Mills deia que no hi havia res més útil com una bona teoria. $\mathrm{Hi}$ afegiria que una bona teoria és el constructe que supera les contradiccions empíriques i el referma com a paradigma. En el cas de la nostra especialitat, la teoria de l'educació es mou en la contradicció definida per la manca de relació entre formació cultural i ocupació en la societat postfordista -o societat industrial avançada-, on I'Index de Desenvolupament Humà és l'únic referent que permet plantejar vies de resposta a la marginalitat social (que continua essent el repte de les ciències socials).

En aquest context, el coneixement pedagògic, com a disciplina social, ve definit per un àmbit metodològic intern -estricte- a la matèria educativa. Així, cada àrea de coneixement aplica un procediment de recerca, anàlisi i interpretació dels fets i elabora unes consideracions que ajuden a estudiar cada procés plantejat en clau interna. Ara bé -i com es propi del conjunt de les ciències socials- la pedagogia -o millor, tipologies de pedagogies- vénen condicionades per variables aparentment externes, conseqüència del model de societat on es desenvolupa l'aplicació educativa. Dic 'aparentment' perquè els contextos macro (generals) i microsociològics (àmbits d'aplicació) tenen una incidència prou determinant en les qüestions de debat disciplinar i en els models epistemològics a desenvolupar en l'àrea de les ciències de l'educació.

En aquest sentit, el volum que ens ocupa significa una aportació d'interès per a aquelles àrees d'anàlisi que tenen un definit perfil sociopedagògic. Em refereixo a la Teoria, la Història i Filosofia de l'educació, a l'Antropologia pedagògica, als Processos i contextos educatius, a la Pedagogia social i a la matèria transversal "Societat, Família i Educació". En aquest sentit, el volum que comentem aporta (per la seva capacitat de síntesi i de relació) elements explicatius que faciliten la comprensió de manifestacions difícils a l'hora de cirscumscriure estrictament la pedagogia a aspectes interns. Com a exemple d'això darrer, el reiterat -i circular- debat sobre el fracàs escolar.

Teoria sociològica moderna, dividida en vint-i-dos capítols, sistematitza i actualitza els corrents de pensament social elaborats i socialitzats al segle vintè. Amb tot, la limitació cronològica secular no implica concloure el decalatge i la crisi de legitimitat científica dels posicionaments metodològics que s'hi especifiquen, sinó que el volum 
coordinat pel sociòleg Salvador Giner té l'originalitat d'incloure nous paràmetres interpretatius -com el de la sociologia analítica (pp. 309-345)-, que proposen la relació entre hipòtesis generalistes, marc de treball empíric (micro) i retorn al nivell de plantejaments generals. I de fet, aquest és el model del quefer científic, que en l'àmbit de la pedagogia remet a la circularitat entre hipòtesis de treball i treball de camp.

Però tant les hipòtesis, com el treball de camp, haurien de tenir en compte -en els àmbits de les ciències de l'educació esmentats anteriorment- els següents paràmetres generals als quals fa esment el volum compilatori citat: la concepció reformista socialdemòcrata- de la modernització capitalista (Lamo de Espinosa, pp. 27-51), els condicionaments estructurals -polítics i socioeconòmics- de les respectives hegemonies culturals (Ariño, pp. 345-383) i la relació intrínseca entre comunicació com a socialització de patrons ideològics, llocs de memòria i imaginaris collectius- i societat (Trinidad Bretones, pp. 413-450). Aquests apartats aporten a la Teoria i Filosofia de l'educació, referents generals on poder contextualitzar la racionalitat pedagògica coetània. Una racionalitat, però, que pot estar qüestionada per una crisi de legitimitat de la modernització "amb rostre humà" (Uriel Beck).

D'altra banda, aquest marc general, amb introducció de variables sociopolítiques, es veu reforçat amb el capítol que tracta sobre el model social basat en la negociació contractual i el denominat diàleg social -empresariat, sindicats i governança(Giner\&PérezYruela, pp. 5173-586). Efectivament, la relació entre ciutadania i el que es concep com a estat del benestar (Moreno, pp. 589-603), introdueix en la disciplina sobre les teories educatives, els processos i contextos pedagògics i en la pedagogia social (polítiques educatives), un marc adient on plantejar la vigència de pràctiques pedagògiques envers collectius extensos objecte del procés de minorització social. També ho fa amb la matèria "Societat, Família, Educació" en remetre a variables culturals i socials a l'hora d'explicar fenòmens com el canvi tipològic de família i l'abast de les polítiques d'igualtat i la relació entre cultures.

Però cal dir que el conjunt d'aquests apartats serveix per a comprendre no pas únicament concepcions conjunturals sobre conflictes sorgits en el temps educatiu, sinó que també és aplicable a la comprensió (sociologia comprensiva) de les condicions de possibilitat pertocants a la historicitat de concepcions educatives alternatives a la política establerta.

Així -com a exemple d'estudis sobre plantejaments modernitzadors en la història de l'educació contemporània-, els volums Quinze pedagogs. La seva influència, avui (Proa, 1995) i El legado pedagógico del siglo XX para la escuela del siglo XXI (Graó, 2009) aprofundeixen sobre la tradició pedagògica moderna -de J.J.Rousseau a $B$. Suchodolski. Amb tot, definir la trajectòria d'aquest trend secular pedagògic ( $\mathrm{i}$ cultural) implica emmarcar concepcions, línies de treball i d'aplicació educatives en el context de (dis)continuïtat social. Per aquesta raó, quan es tracta d'història de l'educació -i per no reduir-la a un seguit positivista d'enfilall de fets- cal fer, alhora, sociologia històrica de l'educació. És a dir, analitzar el sentit dels posicionaments 
pedagògics contemporanis - de la Il-lustració i les seves controvèrsies, a la crisi de la Postmodernitat- significa remetre'ns al coneixement dels respectius models economicopolítics i socials. I aquesta prioritat metodològica ve explicitada en les seccions citades en la compilació sobre models sociològics coetanis objecte del nostre comentari.

Dit tot això, una primera conclusió a la qual hom pot arribar és que les seccions esmentades de l'edició que tractem incideixen en la relació entre sociologia de l'educació (un capítol que trobem a faltar en el tractat comentat) i un enfocament, necessàriament diacrònic de la teoria de l'educació, que ha de tenir en compte, per tant, l'evolució de les doctrines pedagògiques.

Pel que fa als apartats de la teoria de la sociologia moderna, aquests abasten la relació entre marxisme i sociologia (Sampere, pp. 133-153), els moviments socials (Godàs, pp. 553-571) i la crítica a la modernitat (Rodríguez Ibáñez, pp. 649-74). Aquests assaigs són d'utilitat per a l'antropologia pedagògica en reflectir les contradiccions estructurals de la societat capitalista que duu, segons Lipovetsky, a l'hiperindividualisme i a la societat del buit. Aquesta interpretació, símptoma de l'atomització social, pot plantejar-se com a finalitat o com a variable dependent, segons que tinguem en compte una contextualització més àmplia del model de societat. Nogensmenys, les aportacions de l'Escola de Frankfurt -amb L'home unidimensional definit esplèndidament per Herbert Marcuse- i la respota dels moviments socials a polítiques socials restrictives i privatitzadores indiquen que la pedagogia (aplicada) social no ha de ser aliena a les manifestacions grupals que malden per construir la seva pròpia identitat social. Per tant, aquests tres apartats són especialment útils per a concebre la pedagogia com a matèria oberta a fi de copsar (com de fet, remet la seva etimologia) les potencialitats autònomes del subjecte. És a dir, d'utilitat per a situar els enfocaments i reflexions educatives en una concepció sociològica que es plantegi -contràriament a l'estructural-funcionalisme o teoria de sistemes- la possibilitat de crisi de legitimitat sistèmica. Aquest extrem l'aporta el capítol de Rodríguez Ibáñez en tant que conceptua l'illimitat optimisme de creixement de la nostra àrea econòmica dins el que defineix com a "societat del risc" (pp.674-677).

He esmentat l'estructural-funcionalisme per a indicar que, precisament, tenir en compe el necessari plantejament de variables externes del sistema educatiu pot condicionar finalment la viabilitat explicativa de la "teoria dels vasos comunitats" que, com és sabut, redueix la dialèctica implícita en l'estructura social al coneixement dels mecanismes tècnics -gairebé estadístics- que tenen com a finalitat construir (=inventar) burocràticament la reproducció social. I precisament la sociològia crítica inclosa en els darrers capítols esmentats- és la gran aportació del pensament social contemporani. No en va, corrents pedagògics cooperatius dels anys seixanta i setanta foren plantejats (la relació entre principis educatius i relació activa amb la comunitat social) des de la teoria crítica. 
Amb tots aquests aspectes vull dir que els diversos enfocaments que ens ofereix l'edició coordinada per un referent històric de la teoria social, com és Salvador Giner, poden ser, com he intentat de mostrar, útils en matèries, o vessants pedagògics, que per llur caràcter interdisciplinar -història, antropologia, sociologia- obliguen a plantejar interrogants, impulsar recerques i establir hipòtesis que, per la mateixa orientació holística de l'educació, colllaborin a superar explicacions espúries, purament "estètiques", circumstancials o reiteratives, ${ }^{1}$ i aprofundeixin en la complexitat (sense retòrica) del fet social. No d'altra manera es pot extrapolar el raonament de Giner (pp. 67-71) quan fa referència al sentit comunitari de la sociologia, a la finalitat de la pedagogia: l'ètica de l'objectivitat i la seva dimensió aplicada a l'interès comú com a superació del miratge de la neutralitat.

Aquest volum, doncs, és un referent de partença per a desenvolupar raonaments que facilitin una comprensió general i contextualitzada de l'educació (com a procés de participació col·lectiva) i la resolució dels seus laberints. Eduació i societat.

Xavier Ferré Trill. Professor del Departament de Pedagogia de la Universitat Rovira i Virgili.

\section{Notas}

${ }^{1}$ Vegeu el "Iloc comú" en el que s'ha convertit el principi de la "societat líquida" del sociòleg polonès Zygmunt Baumann. Tot un indici del que no ha de ser una explicació sociològica basada en la incertesa indefinida (La Vanguardia, 12-I-2012), p. 56. 